\title{
Toward an in silico models for variation in neuroangiogenesis in retina
}

\author{
Hesam Dashti ${ }^{1}$, Nader Sheibani ${ }^{2}$, Christine Sorenson $^{3}$, Chengyu Liu $^{1}$, Amir H Assadi ${ }^{*}$ \\ From Nineteenth Annual Computational Neuroscience Meeting: CNS*2010 \\ San Antonio, TX, USA. 24-30 July 2010
}

\section{The problem}

Phenotypic variation is ubiquitous. Diversity in behavioral response within a single genotype is ubiquitous. Sources, mechanisms and innovations in variation within a genotype are hardly understood. In neuroscience, the problem of genotype-phenotype relationship is notoriously difficult due to many intermediate layers that mediate between the DNA, the physical structures of cells, and the dynamics of neuroglial and vascular interactions in development and response to environmental stimuli. Neuroangiogenesis in mice retina provides a mechanism that lends itself to detailed study of the relationship between genotype and phenotype.

\section{Research}

The circuitry of the retina is directly affected by genomic perturbations [Markus] Meister et al.. Development of the retinal circuitry plays a fundamental role in the earliest patterns of neuronal connectivity through spontaneous retinal waves [Marla] Feller et al. The branching architectures of nerves and vasculature are also established to develop in parallel. Therefore, it is reasonable to investigate the variation in pattern formation in developing retina as a gateway to understanding variation in fetal brain development and its functional consequences. In this article, we study variations on the branching structures as they occur naturally or due to genomic perturbations, such as gene knockout.

\section{Results}

Angiogenesis is controlled by physical interactions between cells and extracellular matrix as well as

\footnotetext{
* Correspondence: ahassadi@wisc.edu

'Department of Mathematics, University of Wisconsin, Madison, WI 53706, USA
}

soluble antigenic factors, such as VEGF. Variation in morphology for the wild type is due to modulation of signaling. However, the mechanism by which mechanical signals integrate with other microenvironmental cues to regulate neovascularization in retina remains unknown. This article provides an in silico approach towards exploring morphological variation neuroangiogenesis in the mouse retina for the wild type and certain mutants. Specifically, novel algorithms are designed to quantify natural and perturbed variation in morphology; this is most difficult and laborious step towards analysis of Quantitative Trait Loci (QTL) and other quantitative neuro-genetics methods to determine the genomic and other mechanisms that are responsible for morphological variation.

\section{Translational medicine}

On the clinical side, we elucidate potential applications of the computational models to understanding the mechanism of diseases that are characterized by pathological morphologies in angiogenesis, such as diabetes.

\section{Author details \\ 'Department of Mathematics, University of Wisconsin, Madison, WI 53706, USA. ${ }^{2}$ Department of Ophthalmology and Visual Science, University of Wisconsin, Madison, WI 53706, USA. ${ }^{3}$ Department of Pediatrics, University of Wisconsin, Madison, WI 53706, USA.}

Published: 20 July 2010

\section{References}

1. Abbott LF, van Vreeswijk C: Asynchronous states in networks of pulsecoupled oscillators. Phys Rev E Stat Phys Plasmas Fluids Relat Interdiscip Topics 1993, 48:1483-1490.

2. Bower JM, Beeman D: The Book of Genesis. NewYork: Springer-Verlag, 2nd 1998.

3. Ghazanfar AA, Maier JX, Hoffman KL, Logothetis NK: Multisensory integration of dynamic faces and voices in rhesus monkey auditory cortex. J Neurosci 2005, 25(20):5004-5012. 
4. EPFL Neocortical microcircuit database. [http://microcircuit.epfl.ch].

5. Petilla 2005 Convention. [http://www.columbia.edu/cu/biologfaculty/yuste/ petilla/petilla-webpages/Nomenclature/PetillaNomenclaturefinal.pdf].

doi:10.1186/1471-2202-11-S1-P75

Cite this article as: Dashti et al:: Toward an in silico models for variation in neuroangiogenesis in retina. BMC Neuroscience 2010 11(Suppl 1):P75.

Submit your next manuscript to BioMed Central and take full advantage of:

- Convenient online submission

- Thorough peer review

- No space constraints or color figure charges

- Immediate publication on acceptance

- Inclusion in PubMed, CAS, Scopus and Google Scholar

- Research which is freely available for redistribution

Submit your manuscript at www.biomedcentral.com/submit

() BioMed Central 